\title{
The origins and development of the Journal of Horticultural Science and Biotechnology (JHSB) 1919-2019
}

Article

Accepted Version

Dixon, G. R. (2019) The origins and development of the Journal of Horticultural Science and Biotechnology (JHSB) 1919-2019. Journal of Horticultural Science \& Biotechnology, 94 (6). pp. 685-686. ISSN 1462-0316 doi:

https://doi.org/10.1080/14620316.2019.1609781 Available at https://centaur.reading.ac.uk/88156/

It is advisable to refer to the publisher's version if you intend to cite from the work. See Guidance on citing.

To link to this article DOI: http://dx.doi.org/10.1080/14620316.2019.1609781

Publisher: Taylor and Francis

All outputs in CentAUR are protected by Intellectual Property Rights law, including copyright law. Copyright and IPR is retained by the creators or other copyright holders. Terms and conditions for use of this material are defined in the End User Agreement.

www.reading.ac.uk/centaur 
Central Archive at the University of Reading

Reading's research outputs online 


\section{The origins and development of the Journal of Horticultural Science and Biotechnology (JHSB) 1919-2019}

As an introduction to the final issue of the Journal's Centenary Volume, this editorial outlines the history and development of the Journal over its first hundred years. Further detail of the research papers published in the Journal can be found in the Centenary Reviews published in issues 5 and 6 of this volume (Dixon, 2019; Foster, 2019).

Horticultural science is an applied discipline which absorbs advances in the basic sciences, engineering, economics and social studies converting these into useful knowledge. Publishing useful knowledge is the Journal of Horticultural Science and Biotechnology's (JHSB) raison d'etre. The survival of JHSB for a century indicates the successful pursuit of this objective. Now, JHSB enters its second century with a rising impact factor, attracting worldwide authorship and readership and a firm financial platform. The charitable objectives of JHSB are: "to advance research into the science and practice of agriculture with particular reference to horticulture and assist in the dissemination of the results of the that research work by the publication of a Journal". These objectives are approved by the Charity Commissioners which is a department within the Treasury of the United Kingdom Government

\section{Founding of JHSB}

Edward Bunyard founded the Journal of Pomology in 1919 as a personal venture. He was a fourth-generation nurseryman who owned, with members of his family the company George Bunyard and Sons Ltd., of Maidstone Kent which was founded in 1796. Bunyard was a distinguished horticulturist comfortable in the highest echelons of society, an epicurean, man of letters, avid European traveller especially in the South of France and Italy (reviewed Wilson, 2007). Bunyard recognised that horticulture would become progressively a science-based industry. He also believed in what would today be termed "sustainability". One of his major pomological publications was A handbook of hardy fruits (Bunyard 1920) is a timeless discussion of fruit growing and varieties of top and soft fruit.

\section{Partnership with research institutes}

In 1922 the expanding horticultural scientific community took responsibility for the Journal of Pomology. Sir Alfred Daniel Hall (1922), described the new structure which established and guided by a "Publications Committee. The title was changed to The Journal of Pomology and 
Horticultural Science and Bunyard was relieved of the financial burden but retained as the editor. Hall states "The Journal of Pomology and Horticultural Science is intended to be the means of bringing together information gathered from all these sources (research institutes, stations, University College Reading and Royal Horticultural Society Wisley Garden inter alia), of interchanging it with other workers, and particularly of passing it on to the public that can make use of it and translate it into practice-the working fruit growers of the country." The increasing breadth of horticultural science within the ambit of applied biological studies was highlighted by Taylor (1925).

Administratively, Headley Brothers began their responsibilities as publishers which continued successfully managing the Journal's affairs until 2016. Minutes of the Publication Committee of $19^{\text {th }}$ November 1937 recorded the establishment of banking facilities supervised by a group of Trustees.

\section{An independent journal}

The title of the Journal was changed to the Journal of Horticultural Science by the Publications Committee on $27^{\text {th }}$ March 1947. This recognised developing competition from specialist societies. The minutes of the Publications Committee of $10^{\text {th }}$ April 1975 re-stated the Aims and Objectives of the Journal as: "to advance research into the science and practice of agriculture with particular reference to horticulture and assist in the dissemination of the results of the said research work by the publication of a Journal to be called "The Journal of Horticultural Science" which Journal will be available to members of the general public". Up to the 1950 s the parent research institutes (East Malling, Long Ashton and Cambridge Horticultural Research Institute) stood as guarantors for the Journal. Thereafter JHSB has managed its own affairs.

\section{The first fifty volumes}

The achievement of producing 50 volumes was celebrated by Hudson (1977). He noted that from the outset the Journal welcomed papers from beyond its original sponsors and outside the United Kingdom. Hudson also applauded the work of assistant editors for their "fearless criticism of manuscripts and unremitting attention to detail, which makes papers at once more concise and more intelligible". Hudson (like Hall) notes "the express aim of the Journal has been to publish papers that are concerned with scientific investigations into the principles that underly horticultural practice. Hudson concludes "it is confidently expected that the Journal will continue to fulfil a useful function as it moves into its second half century, though it will 
be surprising if there have not been some profound changes in the methods of publishing the results of scientific work by the time the history of the first hundred volumes of the Journal comes to be written".

\section{Expansion and charity status}

The Publication Committee structure was retained until 1994 when it was changed into a Board of Trustees and the then Editor Alun Rees noted (1994) that the size was increased from four to six issues per annum thereby coping with the number of suitable papers being submitted. At this time the Journal became regulated by the Charity Commissioners. The Journal of Horticultural Science and Biotechnology is unique. It is a self -financing charity managed by its Trustees who are beholden only to the British Charity Commissioners. This Journal is wholly free from any outside control, sets its own policies and will continue doing this in the service of horticultural science world-wide into the foreseeable future. In 1997 the title changed slightly after 50 years as the Journal of Horticultural Science, and was extended to the Journal of Horticultural Science and Biotechnology (JHSB) embracing the increasing impact of applied molecular biological studies and methods in horticultural science.

\section{Biotechnology and global reach}

The progress of JHSB was reviewed by Dixon (2006) and by Hillman (2006). It continued reporting research which stimulates crop production but recognised that concerns for environmental impact were emerging and the massive expansion of horticultural science internationally. This is especially evident in the publication of studies based in molecular biology from around the world. Some persistent strands of study remain not least top fruit rootstocks, cold tolerance, post - harvest preservation, pest and pathogen control. The span of crops studied is now greater than anything that The Journal's founders might have imagined. Hillman (2006) directed attention at horticultural research as "a combination of the quest for knowledge of how plants, and their pests and diseases work; how plants respond to and modify their environment; of their nutritional impacts how to culture, harvest, pack and store crops and how to improve plants for the benefit of humankind and to meet the needs of a range of industries will drive horticultural research."

\section{Second century}

In 2015 the JHSB took a major re-structuring step in joining in partnership with the publishing company Taylor and Francis (part of the Informa Group) with a worldwide structure. This is 
immensely beneficial for the Journal providing the use of electronic editorial, publishing and marketing tools, distribution on the internet while still retaining hard copy publishing. The Journal also has developed a robust presence in the social media. Consequently, JHSB confidently now faces its second century publishing robust science and encouraging industrial technology for the benefit of horticulture worldwide. In its centenary year JHSB is publishing reviews of developing applied horticultural science which chart aspects of research which will support industry.

\section{References}

Bunyard E A (1920). A handbook of hardy fruits: more commonly grown in Great Britain, apples and pears. John Murray, London.

Foster, A C (2019). Horticulture meets the periodic table: a century of elemental research. Journal of Horticultural Science and Biotechnology (in review)

Dixon G R (2006). The journal of horticultural science and biotechnology - publishing horticultural science without limitation or inhibition. Journal of Horticultural Science and Biotechnology, 81, 557-558.

Dixon G R (2019) Horticultural science-a century of discovery and application, The Journal of Horticultural Science and Biotechnology, DOI: 10.1080/14620316.2019.1599700.

Hall A D (1922), Forward. Journal of Horticultural Science and Biotechnology, 3 (1), 1-4.

Hillman, J R (2006). Whither or wither horticulture? Horticultural R\&D in the modern era. Journal of Horticultural Science and Biotechnology, 81, 317-318.

Hudson, J P (1977). The journal of horticultural science - the first fifty volumes. Journal of Horticultural Science, 52, 1-8.

Rees A R (1994). Editorial note. Journal of Horticultural Science and Biotechnology, 69 (4) 589.

Taylor H. V. (1925). The importance of applied biology in modern fruit growing. JHSB 5(3), 170-177.

Wilson, E. (2007). The downright epicure-essays on Edward Bunyard. Prospect Books, London. 
Note: Minutes of the Publications Committee and the Board of Trustees are held by the Journal's Secretary/Treasurer.

Professor Geoffrey R Dixon,

Chairman of Trustees

School of Agriculture, Policy and Development, Earley Gate, University of Reading, Reading, Berkshire, RG6 6AR, United Kingdom

Email: geoffrdixon@gmail.com 